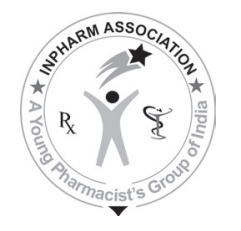

\title{
JVP
}

\section{Spectrophotometric and Reversed-Phase High-Performance Liquid Chromatographic Method for the Determination of Doxophylline in Pharmaceutical Formulations}

\author{
Joshi HR, Patel $A H^{1}$, Captain $A D^{2}$ \\ Shree Swaminarayan College of Pharmacy, Kalol Highway Road, Kalol - 382 721, ${ }^{1}$ Torrent Research \\ Centre, Bhat, Dist.: Gandhinagar - 382 428, ${ }^{2}$ A.R. College of Pharmacy and Institute of Science and \\ Technology for Advance Research (I.S.T.A.R), Vallabh Vidyanagar - 388 120, Gujarat, India
}

Address for correspondence: Mr. Avnish H. Patel; E-mail: avnishhpatel@yahoo.co.in

\begin{abstract}
Two methods are described for determination of Doxophylline in a solid dosage form. The first method was based on ultraviolet (UV)-spectrophotometric determination of the drug. It involves absorbance measurement at $274 \mathrm{~nm}$ ( $\lambda_{\max }$ of Doxophylline) in $0.1 \mathrm{~N}$ hydrochloric acid. The calibration curve was linear, with the correlation coefficient between 0.99 and 1.0 over a concentration range of $0.20-30 \mathrm{mg} / \mathrm{ml}$ for the drug. The second method was based on high-performance liquid chromatography (HPLC) separation of the drug in reverse-phase mode using the Hypersil ODS $\mathrm{C}_{18}$ column $(250 \times 4.6 \mathrm{~mm}, 5 \mathrm{~mm})$. The mobile phase constituted of buffer acetonitrile $(80: 20)$ and $\mathrm{pH}$ adjusted to 3.0, with dilute orthophosphoric acid delivered at a flow rate $1.0 \mathrm{ml} / \mathrm{min}$. Detection was performed at $210 \mathrm{~nm}$. Separation was completed within $7 \mathrm{~min}$. The calibration curve was linear, with the correlation coefficient between 0.99 and 1.0 over a concentration range of $0.165-30 \mathrm{mg} / \mathrm{ml}$ for the drug. The relative standard deviation was found to be $<2.0 \%$ for the UV-spectrophotometry and HPLC methods. Both these methods have been successively applied to the solid dosage pharmaceutical formulation, and were fully validated according to $\mathrm{ICH}$ guidelines.
\end{abstract}

Key words: Doxophylline, HPLC, reversed-phase, UV-spectrophotometry

DOI: $10.4103 / 0975-1483.66791$

\section{INTRODUCTION}

Doxophylline is chemically designated as $7(1,3$ dioxolone2-yl methyl) theophylline. Presence of a dioxolane group in position 7 differentiates it from theophylline. ${ }^{[1]}$ The chemical structure of Doxophylline is provided herewith [Figure 1]. ${ }^{[2]}$

It is a new antibronchospastic drug recently introduced in therapy, with pharmacological properties like theophylline, a potent adenosine receptor antagonist. Doxophylline does not affect gastric acid secretion, either in vivo or in vitro, unlike theophylline. The lack of side- effects with doxophylline indicates that the drug can be used safely and effectively in the treatment of chronic obstructive pulmonary disease (COPD) $\cdot{ }^{[3]}$ Doxophylline inhibits phosphodiesterase (PDE IV) activities with the consequent increase of cyclic AMP, which determines relaxation of the smooth musculature. Doxophylline appears to have decreased affinities toward adenosine A1 and $\mathrm{A} 2$ receptors, which may account for the better safety profile of the drug. Doxophylline does not interfere with calcium influx into the cells or antagonize calcium channel blockers. ${ }^{[4]}$ Unlike aminophylline, it has low secretagogue activity and is suitable for asthmatic patients with peptic ulcer disease. ${ }^{\left[{ }^{[}\right]}$ 


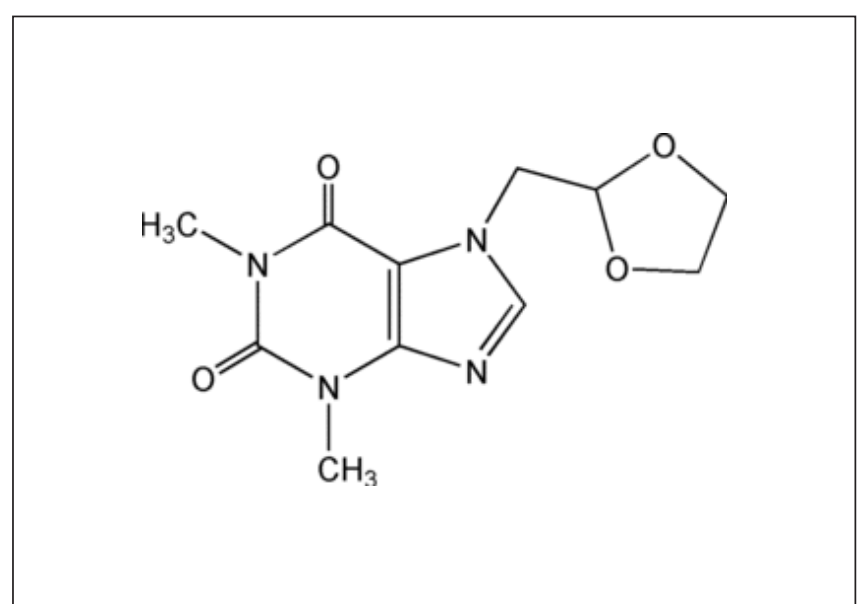

Figure 1: Structure of Doxophylline

Doxophylline is indicated for the treatment of bronchial asthma and COPD. ${ }^{[6]}$

Some analytical methods for quantitative determination of Doxophylline in pharmaceutical formulations are described in the literature, like ultraviolet (UV)spectrophotometry ${ }^{[7]}$ and LC-MS (Liquid ChromatographyMass Spectroscopy). ${ }^{[8-10]}$ At present, no high-performance liquid chromatography (HPLC) and UV-spectrophotometric methods are reported for the estimation of Doxophylline in a tablet dosage form. The purpose of this work is to develop and validate the proposed methods for routine analysis in a quality control laboratory.

\section{EXPERIMENTAL PROCEDURE}

\section{Instrument and condition}

1. UV-visible spectrophotometer - Model UV-1700 (Shimadzu, Tokyo, Japan).

2. HPLC system - Shimadzu LC 2010C integrated system equipped with quaternary gradient pump, 2010C UV-VIS detector, 2010C column oven and 2010C programmable auto sampler controlled by CLASS-VP software. (SHIMADZU USA Manufacturing Inc, 1900, SE $4^{\text {th }}$ Ave, Canby, OR, 97013-4348, North America, USA)

3. Analytical column - Hypersil ODS C 18 ( 250 X $4.6 \mathrm{~mm}$, $5 \mathrm{~mm}$ particle size), (Weber Consulting, Attila u. 38/b. H-2132 Göd, Hungary)

4. Detector - UV visible

5. Chromatographic parameters- Detection at $210 \mathrm{~nm}$, flow rate $1.0 \mathrm{ml} / \mathrm{min}$.

6. Mobile phase - Potassium dihydrogen phosphate $(\mathrm{pH} 3.0 \pm 0.2$ adjusted with orthophosporic acid)acetonitrile $(80: 20, \mathrm{v} / \mathrm{v})$.

7. Diluent - $0.1 \mathrm{~N}$ hydrochloric acid.

\section{Reagents}

1. Doxophylline reference standard - Assigned purity 99.24\% (Cadila Healthcare Limited, Ankleshwar, Gujarat, India).

2. Acetonitrile - AR grade (Spectrochem), Spectrochem Private Limited, Office 221, 2nd Floor, Anand Bhuvan, 17, Babu Genu Road, Princess Street, MUMBAI - 400 002.

3. Orthophosphoric acid - AR grade (E-Merck Limited), E-Merck (India) Ltd, Shiv Sagar Estate, 'A', Dr. A B Road, Worli, Mumbai, 400018, India

4. Commercially available Doxophylline tablet - Claimed to contain $800 \mathrm{mg}$ of the drug. Procured from Zydus Cadila, Ahmedabad, Gujarat, India.

\section{Standard preparation}

For UV-spectrophotometric and HPLC methods

Standard stock solution of $400 \mu \mathrm{g} / \mathrm{ml}$ was prepared by dissolving $40 \mathrm{mg}$ working standard of Doxophylline in $100 \mathrm{ml}$ of diluent. The working standard solution of Doxophylline had a final concentration of $20 \mu \mathrm{g} / \mathrm{ml}$ and was prepared by appropriate dilution from the stock solution.

\section{Sample preparation}

\section{For UV-spectrophotometric and HPLC methods}

Twenty tablets were weighed and crushed into fine powder. An accurately weighed quantity of powder equivalent to about $125 \mathrm{mg}$ of Doxophylline was transferred into a 250 $\mathrm{ml}$ volumetric flask. Add $100 \mathrm{ml}$ of diluent and sonicate it for $30 \mathrm{~min}$ with continuous shaking. Make the volume up to the mark with $0.1 \mathrm{~N} \mathrm{HCl}$. This solution was filtered through a $0.45 \mu \mathrm{m}$ HVLP nylon filter. Make an appropriate dilution to get the final concentration of Doxophylline 20 $\mu \mathrm{g} / \mathrm{ml}$. Appropriated aliquots were subjected to the above methods and the amount of Doxophylline was determined.

\section{UV-spectrophotometric method}

\section{Construction of the calibration curve}

$\lambda_{\max }$ of Doxophylline $(20 \mu \mathrm{g} / \mathrm{ml})$ was determined by scanning the drug solution in diluent and was found to be at $274 \mathrm{~nm}$. To construct Beer's plot for Doxophylline, dilutions were made in diluent using stock solution at different concentration $(4,12,16,20,24$, and $30 \mu \mathrm{g} / \mathrm{ml})$ levels. The drug followed linearity within the concentration range of $4-30 \mu \mathrm{g} / \mathrm{ml}$.

\section{Assay of the tablet formulation}

Twenty tablets were weighed and crushed into fine powder. 
Table 1: System suitability and system precision (for HPLC)

\begin{tabular}{llccc}
\hline Compound & $\begin{array}{l}\text { Retention time } \\
\text { (Mean } \pm \text { SEM) }\end{array}$ & $\boldsymbol{n}$ & T & k' \\
\hline Doxophylline & $6.434 \pm 0.06217$ & 11034.808 & 1.22 & 642.4 \\
\hline$n=$ Theoretical plates, $\mathrm{T}=$ Asymmetry, $\mathrm{k}^{\prime}=$ Capacity factor & & &
\end{tabular}

Table 2A: Characteristics of the Analytical method derived from the standard calibration curve (for UVspectrophotometric method)

\begin{tabular}{lcccccc}
\hline Compound & LOD $\boldsymbol{\mu g} / \mathbf{m l}$ & $\begin{array}{c}\text { LOQ } \boldsymbol{\mu g} / \mathbf{m l} \\
\boldsymbol{n}=\mathbf{5}\end{array}$ & $\begin{array}{c}\text { Linearity } \\
\text { range } \boldsymbol{\mu g} / \mathbf{m l}\end{array}$ & $\begin{array}{c}\text { Correlation } \\
\text { coefficient } \mathbf{r}^{2}\end{array}$ & $\begin{array}{c}\text { Residual standard } \\
\text { regression } \boldsymbol{\sigma}\end{array}$ & $\begin{array}{c}\text { Slope of regression } \\
\mathbf{S}\end{array}$ \\
\hline Doxophylline & 0.07 & 0.2 & $4-30$ & 0.99798 & 0.02569 & 0.00332 \\
\hline
\end{tabular}

LOD $=$ Limit of detection, $\mathrm{LOQ}=$ Limit of quantification

Table 2B: Characteristics of the analytical method derived from the standard calibration curve (for HPLC method)

\begin{tabular}{lcccccc}
\hline Compound & LOD $\boldsymbol{\mu g} / \mathbf{m l}$ & $\begin{array}{c}\text { LOQ } \boldsymbol{\mu g} / \mathbf{m l} \\
\mathbf{n}=\mathbf{5}\end{array}$ & $\begin{array}{c}\text { Linearity range } \\
\boldsymbol{\mu g} / \mathbf{m l}\end{array}$ & $\begin{array}{c}\text { Correlation } \\
\text { coefficient } \mathbf{r}^{2}\end{array}$ & $\begin{array}{c}\text { Residual standard } \\
\text { regression } \boldsymbol{\sigma}\end{array}$ & $\begin{array}{c}\text { Slope of regression } \mathbf{S} \\
\text { Doxophylline }\end{array}$ \\
\hline
\end{tabular}

LOD $=$ Limit of detection, $\mathrm{LOQ}=$ Limit of quantification

Table 3A: Method precision (for UV-spectrophotometric method)

\begin{tabular}{lcccc}
\hline Compound & $\begin{array}{c}\text { Concentration } \\
\boldsymbol{\mu g} / \mathbf{m l} \\
(\mathbf{n}=\mathbf{6})\end{array}$ & $\begin{array}{c}\text { Absorbance } \\
\text { Mean } \pm \\
\text { SEM } \\
(\mathbf{n}=\mathbf{6})\end{array}$ & $\begin{array}{c}\text { \% assay } \\
\text { Mean } \pm \\
\text { SEM } \\
(\mathbf{n}=\mathbf{6})\end{array}$ & $\begin{array}{c}\text { \% RSD } \\
(\mathbf{n}=\mathbf{6})\end{array}$ \\
\hline Doxophylline & 20 & $0.716 \pm$ & $101.75 \pm$ & 0.9 \\
& & 0.00204 & 0.3535 & \\
\hline
\end{tabular}

An accurately weighed quantity of powder equivalent to about $125 \mathrm{mg}$ of Doxophylline was transferred into a 250 $\mathrm{ml}$ volumetric flask. Add $100 \mathrm{ml}$ of diluent and sonicate it for 30 min with continuous shaking. Make the volume up to the mark with $0.1 \mathrm{~N} \mathrm{HCl}$. This solution is then filtered through a $0.45-\mu \mathrm{m}$ HVLP (High Vinyl Liquid Polymer) nylon filter. Make appropriate dilution to get the final concentration of Doxophylline $20 \mu \mathrm{g} / \mathrm{ml}$. Appropriated aliquots were subjected to the above methods and the amount of Doxophylline was determined.

\section{HPLC Method}

\section{Construction of the calibration curve}

To construct Beer's plot for Doxophylline, dilutions were made in the diluent using stock solutions at different concentration $(4,12,16,20,24$ and $30 \mu \mathrm{g} / \mathrm{ml})$ levels. The drug followed linearity within the concentration range of $4-30 \mu \mathrm{g} / \mathrm{ml}$ for Doxophylline at $210 \mathrm{~nm}$.

\section{Assay of the tablet formulation}

Twenty tablets were weighed and crushed into fine powder. An accurately weighed quantity of powder equivalent to about $125 \mathrm{mg}$ of Doxophylline was transferred into a 250$\mathrm{ml}$ volumetric flask. Add $100 \mathrm{ml}$ of diluent and sonicate it for 30 min with continuous shaking. Make the volume up to the mark with $0.1 \mathrm{~N} \mathrm{HCl}$. This solution was filtered through a $0.45-\mu \mathrm{m}$ HVLP nylon filter. Make appropriate dilution to get the final concentration of Doxophylline 20 $\mu \mathrm{g}-\mathrm{ml}$. Appropriated aliquots were subjected to the above methods and the amount of Doxophylline was determined.

\section{RESULT AND DISCUSSION}

System suitability and system precison (For HPLC)

This parameter has been performed before starting any validation parameter each time. The purpose of this parameter is to ensure that system is working properly and it can be used further for analysis and validation. For more details, Table 1.

\section{Linearity}

The plot of absorbances against concentration is shown in Figures 2 and 3. It can be seen that the plot is linear over the concentration range of $0.20-30 \mu \mathrm{g}-\mathrm{ml}$ in UVspectrophotometry and $0.165-30 \mu \mathrm{g} / \mathrm{ml}$ in HPLC for Doxophylline, with correlation coefficients $\left(\mathrm{r}^{2}\right)$ of 0.99798 and 0.99629 , respectively. The obtained results are presented in Tables $2 \mathrm{~A}$ and $2 \mathrm{~B}$.

\section{Standard and sample solution stability}

Standard and sample solution stabilities were evaluated at room temperature for $48 \mathrm{~h}$. The relative standard deviation (RSD) was found to be below $2.0 \%$. It shows that the standard and sample solutions were stable up to $48 \mathrm{~h}$ at 


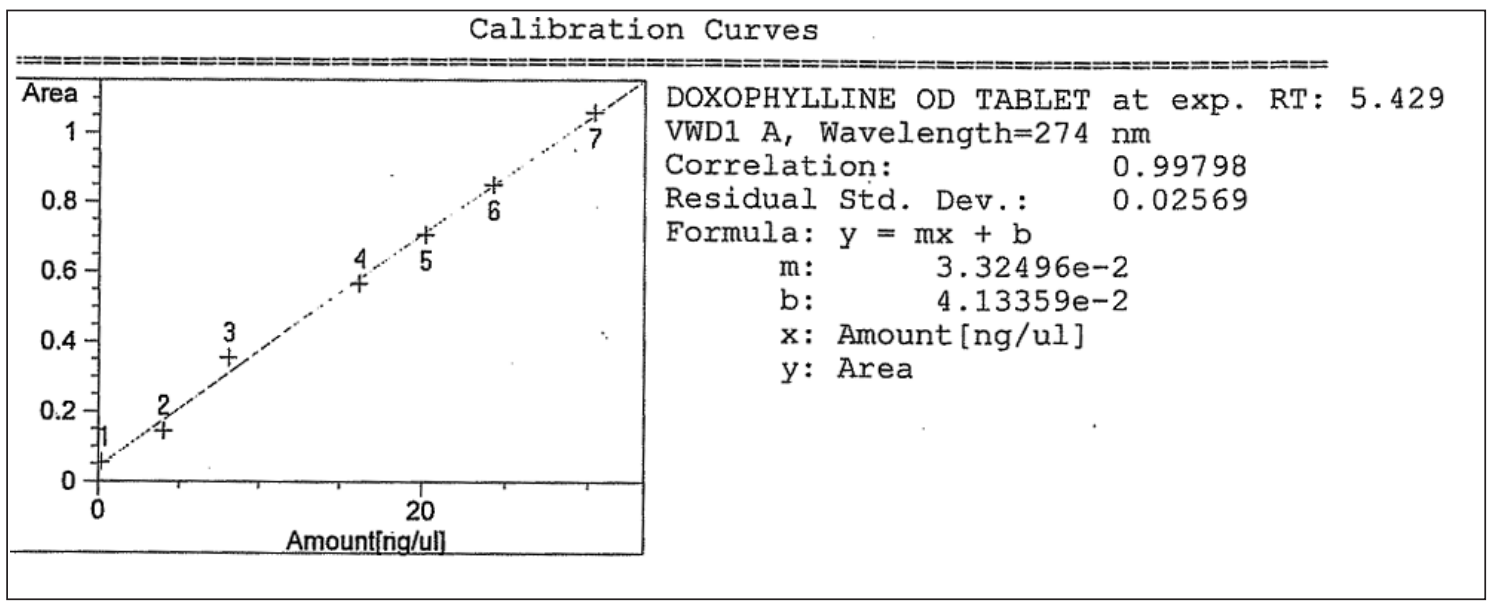

Figure 2: Calibration curve for Doxophylline (for the UV-spectrophotometric method)

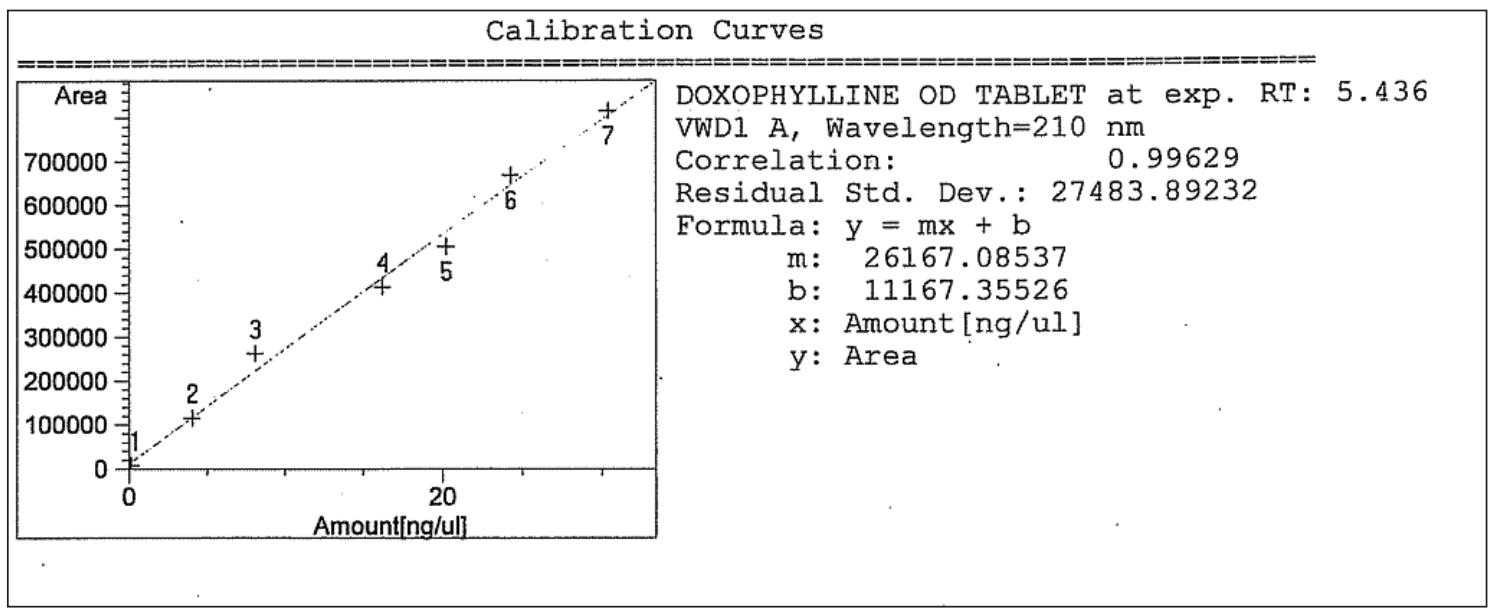

Figure 3: Calibration curve for Doxophylline (high-performance liquid chromatography)

Table 3B: Method precision (for HPLC method)

\begin{tabular}{lcccc}
\hline Compound & $\begin{array}{c}\text { Concentration } \\
\boldsymbol{\mu g} / \mathbf{m l}(\mathbf{n}=\mathbf{6})\end{array}$ & $\begin{array}{c}\text { Retention time } \\
\text { Mean } \pm \text { SEM }(\mathbf{n}=\mathbf{6})\end{array}$ & $\begin{array}{c}\text { \% assay } \\
\text { Mean } \pm \text { SEM }(\mathbf{n}=\mathbf{6})\end{array}$ & $\begin{array}{c}\text { \% RSD } \\
(\mathbf{n}=\mathbf{6})\end{array}$ \\
\hline Doxophylline & 20 & $5.62 \pm 0.0460$ & $101.0 \pm 0.4232$ & 1.0 \\
\hline
\end{tabular}

Table 4A: Method accuracy (for UV-spectrophotometric method)

\begin{tabular}{lcccc}
\hline Level & $\begin{array}{c}\text { Drug added } \\
(\mathbf{m g})\end{array}$ & $\begin{array}{c}\text { Drug recovered } \\
(\mathbf{m g})\end{array}$ & $\begin{array}{c}\text { \% assay (Mean } \pm \text { SEM) } \\
(\boldsymbol{n}=\mathbf{3})\end{array}$ & $\begin{array}{c}\text { \% RSD of assay } \\
(\boldsymbol{n}=\mathbf{3})\end{array}$ \\
\hline Doxophylline & & & & \\
$50 \%$ & 62.05 & 62.41 & $100.6 \pm 0.088$ & 0.2 \\
$100 \%$ & 124.01 & 123.75 & $99.8 \pm 0.409$ & 0.7 \\
$150 \%$ & 185.88 & 186.23 & $100.3 \pm 0.266$ & 0.5 \\
\hline
\end{tabular}

room temperature. Please refer, Spectrum of Standard which is provided as Figure 4 and Chromatograms of Standard and sample which are provided as Figures 5 and 6 respectively.

\section{Method precision}

The RSD for six replicates of the sample solution was $<2.0 \%$, which met the acceptance criteria established for the spectrophotometric and HPLC methods. The obtained results are presented in Tables $3 \mathrm{~A}$ and $3 \mathrm{~B}$.

\section{Accuracy}

Accuracy was performed at three levels: 50, 100 and 150\%. Percentage recovery and low RSD value show the accuracy of the spectrophotometric and HPLC methods. The data are presented in Tables $4 \mathrm{~A}$ and $4 \mathrm{~B}$. 
Table 4B: Method accuracy (for HPLC method)

\begin{tabular}{lcccc}
\hline Level & $\begin{array}{c}\text { Drug added } \\
(\mathbf{m g})\end{array}$ & $\begin{array}{c}\text { Drug recovered } \\
(\mathbf{m g})\end{array}$ & $\begin{array}{c}\text { \%assay (Mean } \pm \text { SEM) } \\
(\mathbf{n}=\mathbf{3})\end{array}$ & \% RSD of assay $(\mathbf{n}=\mathbf{3})$ \\
\hline Doxophylline & & & & \\
$50 \%$ & 62.05 & 62.21 & $100.26 \pm 0.448$ & 0.8 \\
$100 \%$ & 124.01 & 123.41 & $99.5 \pm 0.458$ & 0.8 \\
$150 \%$ & 185.88 & 186.27 & $100.2 \pm 0.321$ & 0.6 \\
\hline
\end{tabular}

Table 5A: Method ruggedness (for UV-spectrophotometric method)

\begin{tabular}{lcc}
\hline Compound & \% assay Mean \pm SEM $(\mathbf{n}=\mathbf{6})$ & \% RSD of assay $(\mathbf{n}=\mathbf{6})$ \\
\hline Day 1, Analyst-1, Instrument-1 & $101.75 \pm 0.3535$ & 0.9 \\
$\quad$ Doxophylline & & \\
$\begin{array}{l}\text { Day 2, Analyst-2, Instrument-2 } \\
\text { Doxophylline }\end{array}$ & $101.01 \pm 0.1973$ & 0.5 \\
\hline
\end{tabular}

Table 5B: Method ruggedness (for HPLC method)

\begin{tabular}{lcc}
\hline Compound & \% assay Mean \pm SEM $(\mathbf{n}=\mathbf{6})$ & \% RSD of assay $(\mathbf{n}=\mathbf{6})$ \\
\hline Day 1, Analyst-1, Instrument-1, Column-1 & & 1.0 \\
$\quad$ Doxophylline & $101.0 \pm 0.4232$ & \\
Day 2, Analyst-2, Instrument-2, Column-2 & & 0.5 \\
Doxophylline & $100.05 \pm 0.20125$ & \\
\hline
\end{tabular}

Table 6: Method robustness (for HPLC method)

\begin{tabular}{|c|c|c|c|}
\hline \multirow{2}{*}{$\begin{array}{l}\text { Compound } \\
\text { Temperature }\end{array}$} & \multirow{2}{*}{$\begin{array}{c}\text { \% RSD in normal } \\
\% \text { RSD normal }\end{array}$} & \multicolumn{2}{|c|}{ Changed condition $(n=5)$} \\
\hline & & $\% \operatorname{RSD}\left(-5^{\circ} \mathrm{C}\right)$ & $\% \operatorname{RSD}\left(+5^{\circ} \mathrm{C}\right)$ \\
\hline Doxophylline & 1.0 & 0.18 & 1.05 \\
\hline $\mathrm{pH}$ & $\%$ RSD normal & \% RSD (-0.2 unit) & $\%$ RSD (+0.2 unit) \\
\hline Doxophylline & 1.0 & 0.19 & 0.55 \\
\hline Flow rate & $\%$ RSD normal & $\% \operatorname{RSD}(-10 \%)$ & $\% \operatorname{RSD}(+10 \%)$ \\
\hline Doxophylline & 1.0 & 0.10 & 0.19 \\
\hline Mobile phase ratio & $\%$ RSD normal & $\% \operatorname{RSD}(-2 \%)$ & $\% \operatorname{RSD}(+2 \%)$ \\
\hline Doxophylline & 1.0 & 0.08 & 0.19 \\
\hline
\end{tabular}

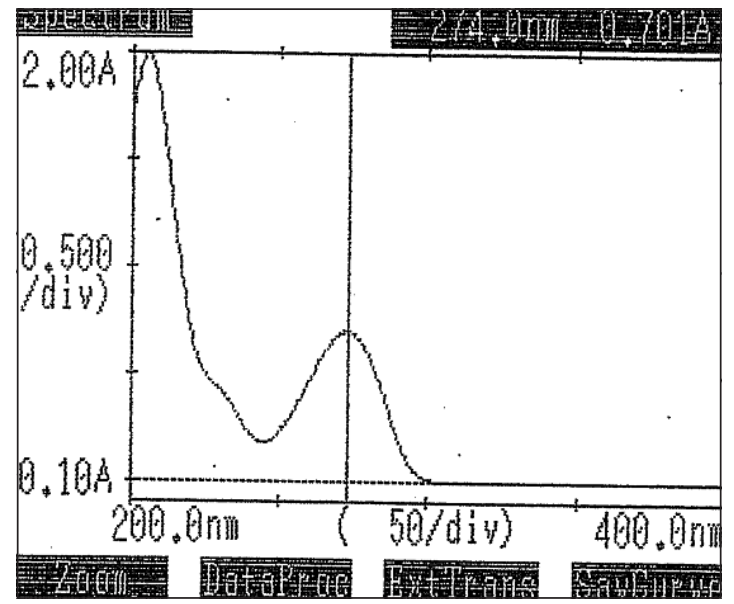

Figure 4: Spectrum of Doxophylline $(20 \mu \mathrm{g} / \mathrm{ml})$ in $0.1 \mathrm{~N}$ hydrochloric acid by the ultravioled-visible spectrophotometer

\section{Method ruggedness}

Ruggedness test was determined between two different analysts, instruments and columns. The value of RSD below $2.0 \%$ showed ruggedness of the developed spectrophotometric and HPLC methods. The results of ruggedness are presented in Tables $5 \mathrm{~A}$ and $5 \mathrm{~B}$.

\section{Method robustness}

The method was found to be robust as small but deliberate changes in the method parameters had no detrimental effect on the method performance, as shown in Table 6. The content of the drug was not adversely affected by these changes, as evident from the low value of RSD, indicating that the method is robust.

\section{Specificity}

There was no interference from sample placebo, and peak purity of Doxophylline was 0.99629. This indicates that the developed analytical method was specific for its intended purpose. 


\section{DISCUSSION}

\section{For UV-spectrophotometric method}

The proposed analytical method is simple, accurate and reproducible. Doxophylline showed $\lambda_{\max }$ at $274 \mathrm{~nm}$. The advantages lie in the simplicity of sample preparation and the cost economic reagents used. The contribution of another important factor is its limit of detection (LOD). Results from statistical analysis of the experimental results were indicative of satisfactory precision and reproducibility. Hence, this spectrophotometric method can be used for analysis of different solid dosage formulations in commercial quality control laboratories.

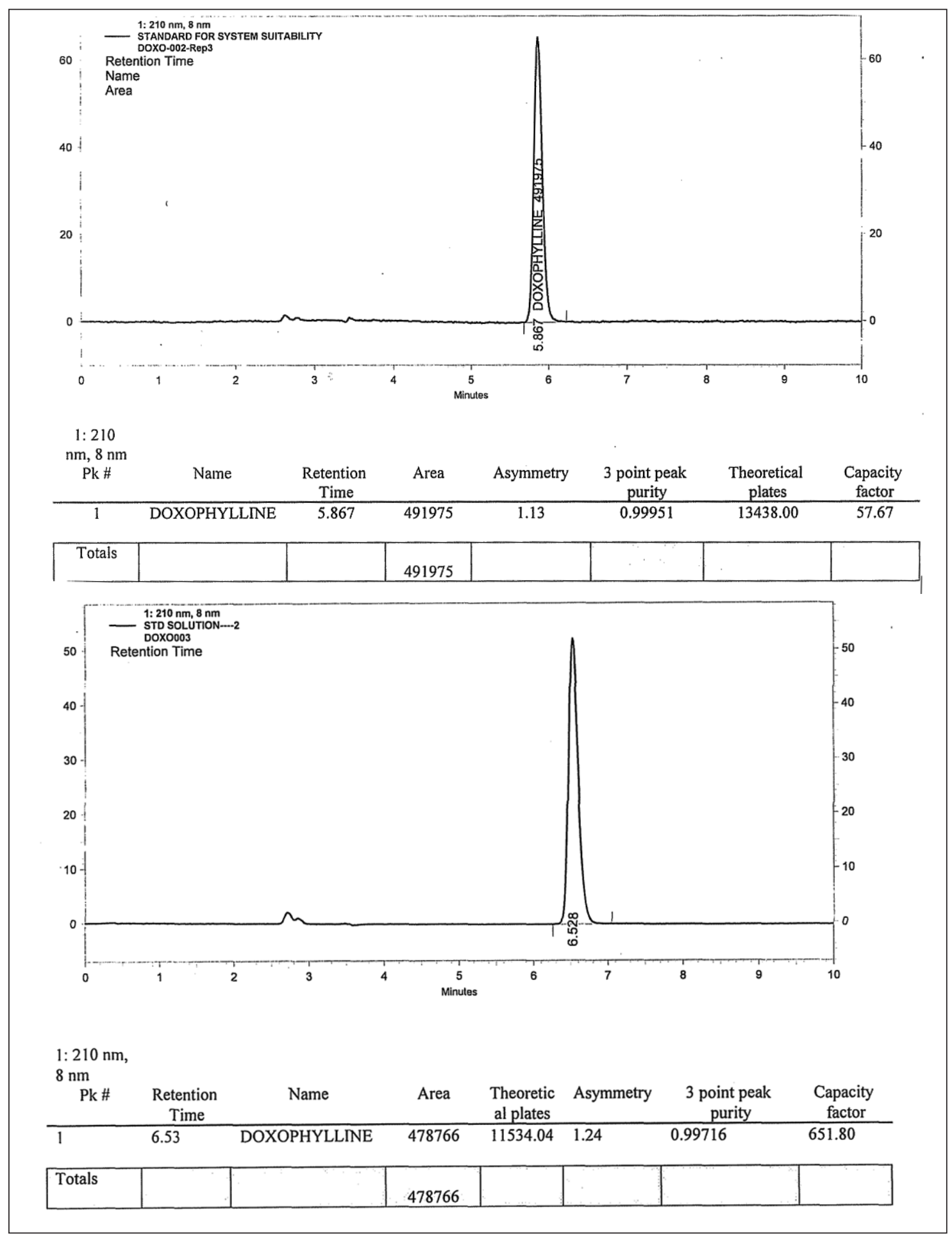

Figure 5: Chromatogram of the standard solution 


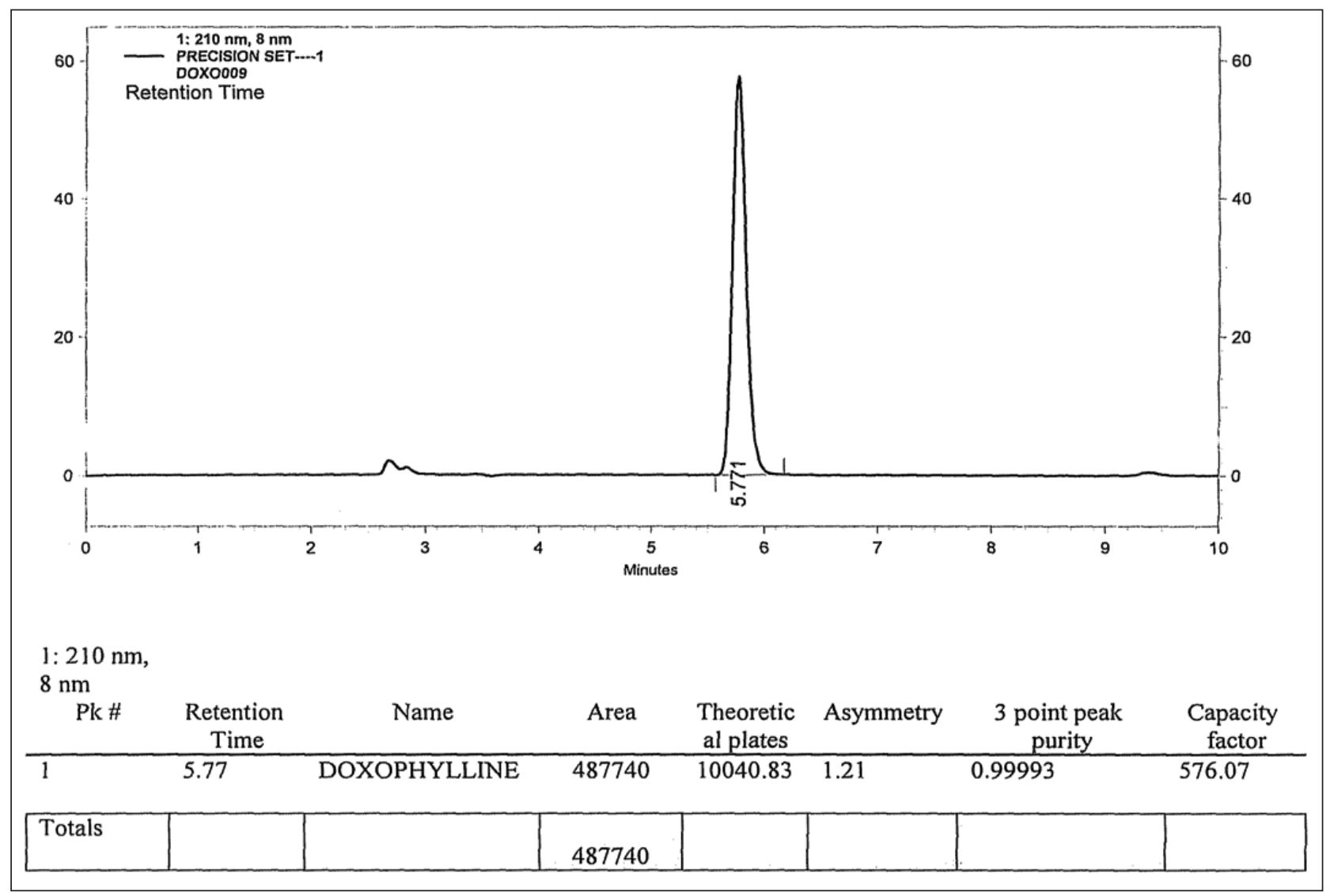

Figure 6: Chromatogram of the sample solution

Table 7: Comparison between UV and HPLC Method

Parameter
Mechanism
Accuracy and precision
Cost of analysis
Reagents/solvents/diluents/mobile phase

Analysis of compounds

Sensitivity

Instrumentation

Speed

Resolution

Type of test/analysis

Useful at scale

Applications

Degradation/by products

Calculation

\section{UV method}

Measurement of absorbance of samples containing only one absorbing component

Low compared to the RP-HPLC method Very low

Use of a polar solvent generally is sufficient

Polar substances having $\lambda_{\text {max }}$ between 200 and $400 \mathrm{~nm}$

Limited in sensitivity

Easy to operate

Compared to HPLC, analysis can be completed within lesser time

Low resolution compared to the HPLC method. Required to go for first and second derivative spectrophotometric methods

It can be use as a confirmatory test for a particular compound

Useful at laboratory scale at the primary level

Useful to find out the qualitative parameter, like $\lambda_{\max }$ of a particular compound

Can be analyzed simultaneously

Calculations have to be performed manually based on the $\lambda_{\max }$ of a particular compound

\section{HPLC method}

Measurement of absorbance and separation (partition) of samples containing more than one absorbing component at a time

Very accurate and precise

High

Use of mobile phase having a combination of either buffer and polar solvent and/or use of two polar solvents

Substances can be analyzed beyond the limit provided in the UV method due to the wider variety of the detector being employed Greater sensitivity (as various detectors can be employed)

Compared to the UV method, complex to operate

Time required for analysis depends on the nature of the molecule to be analyzed

Greater resolution (wide variety of stationary phases)

It is used as a specific identification test for a particular compound

Useful at a large scale, where complex molecules have to be analyzed

Useful to find out the quantitative parameters, like retention time of a particular compound

Can be analyzed within one analysis

Calculations are performed by the integrator itself 


\section{For HPLC}

Considering the efficiency of HPLC, an attempt has been made to develop simple, accurate, precise, rapid and economic methods for estimation of Doxophylline in a solid dosage form. Thus, the method described enables quantification of Doxophylline. The advantages lie in the simplicity of sample preparation and the cost-economic reagents used. The contribution of another important factor is its LOD. Results from statistical analysis of the experimental results were indicative of satisfactory precision and reproducibility. Hence, this HPLC method can be used for the analysis of different solid dosage formulations in commercial quality control laboratories.

The comparative advantages and disadvantages of the UV-spectrophotometric method and reverse-phase HPLC method has been provided herewith.

\section{ACKNOWLEDGMENTS}

The authors are thankful to Zydus Cadila Limited, Ahmedabad, India for providing reference standards and all facilities to complete this research work.

\section{REFERENCES}

1. Bagnato GF. Tolerability of doxofylline in the maintenance therapy of pediatric patients with bronchial asthma. Eur Rev Med Pharmacol Sci 1999;3:255-60.

2. Chen HX, Tu B, Shu Z, Ma XJ, Jin ZM. 7-(1,3-Dioxolan-2-ylmethyl)1,3-dimethyl-3,7-dihydro-1H-purine-2,6-dione, International Union of Crystallography. Acta Crystallographica Section E, Structure Reports Online, organic compounds. Acta Cryst 2007;63:0726-7.

3. Franzone JS, Cirillo R, Barone D. Doxofylline and Theophylline are xanthines with partly different mechanism of action in animals. Drugs Exp Clin Res 1988;14:479-89.

4. Dini FL, Cogo R. Doxofylline: A new generation xanthine bronchodilator devoid of major cardiovascular adverse effects. Curr Med Res Opin 2001;16:258-68.

5. Lazzaroni M, Grossi E, Bianchi Porro G. The effects of intravenous doxofylline or amino group on gastric secretion in duodent ulcer patients, J Aliment Pharmacol Ther 1990;4:643-9.

6. Grossi E, Biffignandi P, Franzone JS. Doxofylline: Pharmacological profile and a review of clinical studies. J Riv Eur Sci Med Farmacol 1988;10:415-30.

7. Kamila MM, Mondal N, Ghosh LK. Development and Validation of Spectrophotometric method for estimation of anti-asthmatic drug doxofylline in bulk and pharmaceutical formulation. Indian J Chem Technol 2007;14:526-8.

8. Lagana A, Bizzarri M, Marino A, Mancini M. Solid phase extraction and high performance liquid chromatographic determination of doxofylline in plasma. Biomed Chromatogr 1990;4:205-7.

9. Tagliaro F, Dorizzi R, Frigerio A, Marigo M. Non-extraction HPLC method for simultaneous determination of dyphylline and doxofylline in serum. J Clin Chem 1990;36:113-5.

10. Sreenivas N, Narasu ML, Shankar BP, Mullangi R. Development and validation of a sensitive LC-MS/MS method with electrospray ionization for quantitation of doxofylline in human serum: Application to a clinical pharmacokinetic study. Biomed Chromatogr 2008;22:654-61.

Source of Support: Nil, Conflict of Interest: None declared. 